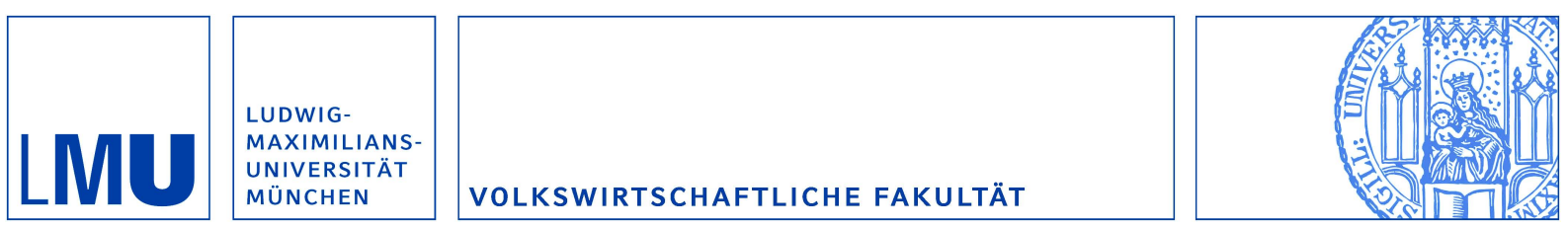

Haufler, Andreas; Mardan, Mohammed und Schindler, Dirk:

Optimal Policies against Profit Shifting: The Role of Controlled-Foreign-Company Rules

Munich Discussion Paper No. 2016-6

Department of Economics

University of Munich

Volkswirtschaftliche Fakultät

Ludwig-Maximilians-Universität München

Online at https://doi.org/10.5282/ubm/epub.27745 


\title{
Optimal Policies against Profit Shifting: The Role of Controlled-Foreign-Company Rules*
}

\author{
Andreas Haufler ${ }^{\dagger}$ \\ Mohammed Mardan $\ddagger$ \\ University of Munich, NoCeT and CESifo \\ ETH Zurich and NoCeT
}

\author{
Dirk Schindler ${ }^{\S}$ \\ Norwegian School of Economics, NoCeT and CESifo
}

April 2016

\begin{abstract}
By introducing controlled-foreign-company (CFC) rules, the parent country of a multinational firm reserves the right to tax the income of the firm's foreign affiliates if the tax rate in the affiliate's host country is below a specified threshold. We identify the conditions under which binding CFC rules are part of the optimal tax mix when governments can set the statutory tax rate, a thin capitalization rule and the CFC rule. We also analyze the effects of economic and financial integration on the optimal policy mix. Our results correspond to the actual development of anti-avoidance rules in OECD countries.
\end{abstract}

Keywords: Multinationals, profit shifting, controlled foreign company rules, thin capitalization rules

JEL classification: H25, H73, F23

${ }^{*}$ Paper presented at seminars and conferences in Bergen, Lugano, Munich, Nuremberg, Uppsala and Tübingen. We thank conference participants, in particular Thiess Büttner, Carsten Eckel, Dominika Langenmayr, Guttorm Schjelderup, Michael Stimmelmayr and Georg Wamser for helpful comments and Lisa Essbaumer and Tobias Hauck for excellent research assistance. The paper was started when Dirk Schindler was a guest researcher at the CES in Munich and continued when Andreas Haufler visited NHH in Bergen. We wish to thank members of both institutions for their hospitality and support.

${ }^{\dagger}$ Seminar for Economic Policy, Akademiestraße 1, D-80799 Munich, Germany; e-mail: Andreas.Haufler@econ.lmu.de; phone +49-8921803858.

${ }^{\ddagger}$ Department of Management, Technology and Economics, Leonhardstrasse 21, CH-8092 Zürich, Switzerland; e-mail: mardan@kof.ethz.ch; phone +41 446338622.

$\S$ Norwegian School of Economics, Department of Accounting, Auditing and Law, Helleveien 30, 5045 Bergen, Norway; email: Dirk.Schindler@nhh.no; phone +47-55959628. 


\section{Introduction}

Controlled-foreign-company (CFC) rules have become an increasingly important policy instrument for governments in their attempt to curb profit shifting by multinational companies and to protect national corporate tax bases. CFC rules apply to so-called 'passive income' like interest payments and royalties which can easily be placed in affiliates in tax havens without having a substantial physical presence there. ${ }^{1}$ By classifying a low-taxed affiliate whose primary activity is to provide debt or patent services to other affiliates in the same corporate group as an affiliate under CFC legislation, the tax authority in the parent country of the multinational thus reserves the right to tax the profits of the affiliate in the tax haven, adding the affiliate's income in the tax haven to the profits declared in the parent country. CFC rules therefore override the tax-exemption principle that most countries now apply for the taxation of multinational companies. ${ }^{2}$ Typically, CFC rules stipulate a minimum effective tax rate that must be levied in a host country, in order to avoid additional taxation in the parent country. In doing so, CFC rules reduce the tax gain for multinationals from placing valuable assets like equity or patents in a tax haven.

In recent years, there has been an active policy discussion surrounding CFC rules. In particular, the OECD's 'Action Plan on Base Erosion and Profit Shifting' calls for introducing and strengthening CFC rules in its member countries as one of the core measures to combat 'excessive' deductions for interest expenses and other financial transactions (OECD, 2013, action 3). Since then, the OECD has worked out a detailed set of recommendations on how this strengthening of CFC rules is to be implemented (OECD, 2015). At the same time, CFC rules face legal challenges, at least in Europe. In its so-called Cadbury-Schweppes decision, the European Court of Justice (ECJ) has ruled that CFC rules restrict the freedom of establishment within the European Economic Area and can thus not be used for affiliates that operate within this area and are headquartered in one of its member states (see Ruf and Weichenrieder, 2013). Despite these important policy concerns, however, CFC rules have so far been left out of theoretical analyses of how governments respond to debt and profit shifting activities of multinational firms. ${ }^{3}$

In this paper, we address two main issues involving $\mathrm{CFC}$ rules. First, we ask under which conditions CFC rules are part of the optimal tax mix when governments have multiple instruments to control tax avoidance strategies of multinational companies. We focus

\footnotetext{
${ }^{1}$ See Dischinger and Riedel (2011) for evidence that patents are placed in low-tax countries and Bergin (2012) for a case study of tax avoidance in the United Kingdom. The issue of which countries become tax havens is analyzed by Dharmapala and Hines (2009).

${ }^{2}$ Under the tax-exemption method, the parent country does not tax the profits of foreign affiliates of a resident multinational company. This scheme, also labelled the 'source country principle' of corporate taxation, is applied by most OECD countries, with the prominent exception of the United States. See Becker and Fuest (2010) for a recent discussion and analysis.

${ }^{3}$ In contrast, there is a small empirical literature analyzing the effects of CFC rules, which is summarized below.
} 
on the internal borrowing decisions of multinationals, which empirically are one of the main channels by which profits are transferred from high-tax to low-tax countries (see Egger et al., 2014, for recent evidence). In this context, a core issue is why CFC rules are used alongside thin-capitalization rules, which are the primary policy instrument of governments to address debt shifting in multinational companies. ${ }^{4}$ In a second step, we then analyze how closer integration in real and financial markets affects the optimal mix of thin-capitalization and CFC rules.

In 2014, more than 30 countries worldwide used CFC rules to limit profit shifting by multinational companies. ${ }^{5}$ Table 1 summarizes both CFC rules and thin-capitalization rules of all OECD countries for which we could retrieve data for the years 2000 (or 2004) and 2014, and compares the regulation over time. As the table shows, most countries with CFC rules also employ thin-capitalization rules to limit debt shifting by multinationals. CFC rules are characterized by the minimum tax rate that a host country must levy to avoid CFC taxation in the parent country of the multinational. The closer this minimum tax rate is to the statutory corporate income tax rate in the parent country, the stricter is the CFC rule. By comparison, thin-capitalization rules are characterized either by a 'safe-harbor' debt-to-equity ratio for which interest payments are always tax-deductible, or directly by a share of interest payments in relation to EBIT(DA). In either case, a higher ratio implies a more lenient thin-capitalization rule. The final two columns in Table 1 indicate that many countries have tightened their thin-capitalization rules and several have tightened their CFC rules since the year 2000, whereas rules have been relaxed only in isolated cases.

$* * * * * * * * * * * * * * * * * * * * * *$ Insert Table 1 here $* * * * * * * * * * * * * * * * * * * * * *$

To study the role of CFC rules in a setting with multiple policy instruments, we set up a model of two symmetric countries and a continuum of tax havens with different tax rates. There are three types of firms in each country: national firms, domestic multinationals, and foreign multinationals. All firms choose their investment levels and the multinational firms additionally choose the tax-optimized financial structure of their investment. This implies that investments in the home country are financed by internal loans from an affiliate in the tax haven, provided that the interest cost of these loans are tax-deductible

\footnotetext{
${ }^{4} \mathrm{~A}$ setting that would be analogous to the one studied here is where transfer pricing in MNCs is primarily addressed by the arm's length principle, but this principle may be supplemented by CFC legislation. In such a setting, we would expect that CFC rules are part of the optimal policy mix under conditions that are very similar to the ones derived here. We have chosen to focus on debt shifting because the enforcement of the arm's length principle is more difficult to model (see, e.g., Keuschnigg and Devereux, 2013) than the thin-capitalization rules introduced here.

${ }^{5} \mathrm{CFC}$ rules were first introduced as 'Subpart F' legislation in the United States in 1964. Germany followed in 1972, using the US rules as a blue print. See Deloitte (2014) for a recent overview of CFC rules employed worldwide, and Lang et al. (2004) for a detailed discussion of CFC rules from a legal perspective.
} 
in the home country. The home and the foreign countries' governments can tax all firms by means of the statutory corporate tax rate and they can additionally use both a thin-capitalization rule and a CFC rule to control the financial choices of multinational firms. The statutory tax rate is legally constrained to be equal for all types of firms, and the thin-capitalization rule must be the same for domestic and foreign multinationals. ${ }^{6}$ The motivation for additionally introducing a CFC rule is that thin-capitalization rules typically formulate a 'safe-harbor' threshold of debt or interest only, which multinational companies can always deduct from their corporate tax base. In practice, multinationals have various ways to 'stretch' these existing limits, for example by introducing financial holding companies (Weichenrieder and Windischbauer, 2008). Such 'excess leverage', which typically comes at a cost to the firm, can then be effectively controlled only by a CFC rule.

Our analysis delivers the following results. In the non-cooperative policy optimum, each government will generally set the thin-capitalization rule so as to permit multinationals operating in the home country to deduct some internal debt from the corporate tax base. This measure selectively reduces the effective cost of capital for multinational companies only, stimulating the location of internationally mobile investment of (home- and foreignowned) multinationals in the home country. Therefore, some effective tax discrimination between purely domestic and multinational firms will occur in the decentralized policy optimum. In addition, a binding CFC rule will be set by each government, if the multinational's choice of excess leverage responds elastically to the introduction of the CFC rule, and if this outweighs the negative effects on the domestic multinational's investment decision and on the profits of its foreign affiliates. Moreover, in the presence of transaction costs for foreign direct investment (FDI), countries would like to discriminate between the effective taxation of domestic and foreign multinationals, in favour of the latter, but cannot do so via the thin-capitalization rule. Since thin-capitalization rules restrict the amount of tax-deductible internal debt for all multinational entities that operate in the home country, whereas CFC rules bind all affiliates worldwide of domestic multinationals, governments can use the $\mathrm{CFC}$ rule to bring about the desired increase in the effective taxation of domestic vis-à-vis foreign multinationals. Therefore, a tax optimum results where domestic firms, domestic multinationals, and foreign multinationals are all taxed at different effective rates.

Based on an initial equilibrium where both thin-capitalization and CFC rules are set at interior levels, we then analyze the effects of economic and financial integration on the optimal mix of thin-capitalization and CFC rules. A reduction in the transaction costs for FDI ('economic integration') leads to a tightening of thin-capitalization rules, because

\footnotetext{
${ }^{6}$ At least within the European Economic Area, thin-capitalization rules cannot be designed in a way that discriminates between domestic and foreign MNCs. See the Lankhorst-Hohorst ruling of the European Court of Justice in 2002.
} 
a higher level of FDI by foreign-owned firms makes it more costly to allow internal debt to be deducted from the domestic tax base. As the tightening of the thin-capitalization rule also affects domestic investment, however, the home-based multinational is partly compensated for this increase in its cost of capital by means of a laxer CFC rule. In contrast, a reduction in the costs of debt shifting to the tax haven ('financial integration') will lead to a simultaneous tightening of both thin capitalization rules and CFC rules. Both of these measures increase the corporate tax base and prevent the multinational companies from taking advantage of the reduced costs of debt shifting to the tax haven by increasing its 'excess leverage'. Taking both real and financial integration together, a clear-cut incentive emerges for countries to tighten their thin-capitalization rules, whereas the case for tighter CFC rules is more mixed. This theoretically derived pattern corresponds to the actual policy changes summarized in the last two columns of Table 1 which show that thin-capitalization rules have been tightened in more countries, and relaxed in fewer, as compared to CFC rules.

The existing literature on CFC rules is almost exclusively empirical. ${ }^{7}$ Ruf and Weichenrieder (2012) analyze the German CFC rules using a detailed database provided by the German central bank. They find that German CFC rules are very effective in curbing passive investment and have a strong impact on the decision of where to locate internal banks and profit centers. Ruf and Weichenrieder (2013) study the impact of the recent Cadbury-Schweppes ruling of the ECJ on German multinationals and find some evidence that these have relocated internal profit centers from countries outside the European Economic Area, where German CFC rules can still be employed, to countries within the European Economic Area. Egger and Wamser (2015) focus instead on the question of how CFC rules affect multinationals' real investment decisions, using a regression discontinuity design at the thresholds where CFC rules become binding. They find a substantially negative local treatment effect on real investment around the thresholds, implying that a binding CFC rule significantly increases effective capital costs.

The only studies on CFC rules not using German data are Altshuler and Hubbard (2003) and Mutti and Grubert (2006). Altshuler and Hubbard look at US multinationals' income from financial services and rely on changes in the 'Subpart F' legislation in the Tax Reform Act of 1986. Their findings suggest that tighter U.S. CFC rules restricted tax deferral by U.S. multinationals. Mutti and Grubert, however, point out that there is an increased use of so-called 'check-the-box' rules, introduced in 1997, which allow U.S. multinationals to work around the United States' CFC rules. ${ }^{8}$

\footnotetext{
${ }^{7}$ To the best of our knowledge, the only theoretical contribution is Weichenrieder (1996). He analyzes the effect of CFC rules on capital investment and shows that CFC rules increase capital costs and decrease the foreign investment of domestic multinationals. His analysis does not model debt shifting explicitly, however, and it does not derive optimal CFC rules or other tax policies towards multinationals.

${ }^{8}$ These rules give multinational companies the option to create hybrid entities for tax purposes. Affiliates in tax havens are still treated as resident companies by their host governments, but they are consolidated with another foreign, mostly high-taxed affiliate by the Internal Revenue Service (IRS), if
} 
In comparison to $\mathrm{CFC}$ rules, thin-capitalization rules have received some more attention in the recent literature. From a theoretical perspective, Hong and Smart (2010) and Haufler and Runkel (2012) show that thin-capitalization rules can be used as an instrument to differentiate between the effective taxation of domestic and multinational firms. In a tax competition equilibrium, thin-capitalization rules will then be set inefficiently lax, in order to attract investment by multinational firms. ${ }^{9}$ Mardan (2015) compares the effects of alternative thin-capitalization rules. From an empirical perspective, there is substantial evidence that thin-capitalization rules are effective in restricting internal borrowing and debt shifting, but they also have negative effects on real investment activity. Examples of this literature are Weichenrieder and Windischbauer (2008), Overesch and Wamser (2010), Büttner et al. (2012, 2014), and Blouin et al. (2014).

The remainder of this paper is organized as follows. Section 2 presents our model and derives the optimal financing and investment decisions of national and multinational firms. Section 3 turns to the optimal tax policy choices made by each country's government. Section 4 analyzes the effects of economic and financial integration on optimal thin-capitalization and CFC rules. Section 5 discusses several extensions of our main analysis and Section 6 concludes.

\section{The Model}

\subsection{The basic framework}

We set up a model of two countries, a home country labeled $h$ and a foreign country labeled $f$. Additionally, there exists a continuum of tax-haven countries offering preferential effective tax rates $t_{k}$, which are continuously distributed in the range $\left[0, t_{h}\right)$. Capital is perfectly mobile across countries and countries $h$ and $f$ are small in world capital markets so that the rate of return to capital is fixed at $r>0$.

There are two representative multinational companies (henceforth MNCs), one headquartered in each of countries $h$ and $f$. Each MNC has a producing affiliate in both countries $h$ and $f$, and a financial center in one of the tax-haven countries. ${ }^{10}$ Furthermore, there is also one purely national firm in each country $h$ and $f$. The division between national and multinational firms is exogenous to our analysis, arising for example from differential fixed costs of setting up an 'internationalized' organizational structure. ${ }^{11}$

a U.S. multinational chooses the check-the-box option. Hence, the IRS views such tax-haven affiliates as branches, rendering the U.S. CFC rules ineffective. Blouin and Krull (2015) find that these 'check the box' regimes triggered a $6.4 \%$ reduction in effective tax rates for U.S. multinationals, in particular benefitting their non-US income.

${ }^{9}$ An analogous argument holds for a lax enforcement of the arm's-length-principle, which allows the multinational to shift profits to a tax haven. See Peralta and van Ypersele (2006).

${ }^{10} \mathrm{We}$ assume that all affiliates are fully owned by the parent company. For an analysis of debt shifting in the presence of variable ownership structures, see Schindler and Schjelderup (2012).

${ }^{11}$ This follows most of the literature on discriminatory tax competition, which assumes exogenous 
All firms use capital to produce a homogenous output good they sell in the world market at a price normalized to one. The output good is produced with capital and some fixed factor, leading to a production function with positive but decreasing returns to investment. Production technologies are allowed to differ between national firms and MNCs. For the national firms, the capital use is denoted by $d_{i}$, with $i \in\{h, f\}$, and production is given by $g\left(d_{i}\right)$. For the MNCs, capital use is $k_{i}^{j}$, where the superscript $j$ denotes the ownership country (i.e., the country where the headquarters reside) and the subscript $i$ indicates the country where capital is employed. Production by the MNCs is given by $f\left(k_{i}^{j}\right)$.

For simplicity, our analysis ignores external capital markets and assumes that all firms can raise sufficient equity to finance their optimal investment levels. Thus, all investment by national firms will be financed by equity. MNCs can, however, place their equity in the tax-haven affiliate, which then becomes an internal bank and grants internal loans to the affiliates in countries $h$ and $f$. This generates interest income in the tax haven but deductible interest expenses in countries $h$ and $f$, in total leading to aggregate tax savings for the MNC. ${ }^{12}$

The governments of countries $h$ and $f$ can deploy three different tax instruments. These are $(i)$ the corporate tax rate $t_{i} ;(i i)$ a thin-capitalization rule that is represented by a safeharbor debt-to-asset ratio $\lambda_{i}$; and (iii) a CFC rule that is characterized by a minimum tax rate $\tau^{j}$ that the tax haven must levy to avoid taxation of the MNC's passive income in the headquarters country $j$. These three policy instruments affect the decisions of MNCs by changing their effective tax rates and hence their cost of capital.

The thin-capitalization rule permits all MNCs investing in a host country $i$ to shift internal interest payments to the affiliate in the tax haven up to a safe-harbor ratio $0 \leq \lambda_{i} \leq 1$ of (internal) debt to capital employed. As long as this safe-harbor ratio is not exceeded, we assume that the internal loan transaction with the tax-haven affiliate is not associated with any transaction costs for the firm. Hence, given the tax savings, affiliates will always find it optimal to engage in internal lending until the safe-harbor share $\lambda_{i}$ of internal interest payments is exhausted.

If financial leverage exceeds the safe-harbor ratio, tax deductibility on 'excessive' interest expenses would be denied by the thin-capitalization rule, because violation of the safeharbor ratio is taken as an indication that the capital structure is not at arm's length. If the MNC can prove the opposite, however, additional tax-deductible interest expenses are still possible. ${ }^{13}$ Moreover, MNCs typically have additional ways to 'stretch' existing thin-capitalization rules, for example by utilizing holding structures for which higher

differences in the international mobility of capital tax bases. For an analysis that endogenizes the degree of firm mobility, see Bucovetsky and Haufler (2008).

${ }^{12}$ In our setting, internal debt is therefore used exclusively in order to save taxes. For an analysis where internal debt reduces the MNC's capital cost under capital market imperfections, see Mardan (2015).

${ }^{13}$ For more detail, see Ruf and Schindler (2015), sections 2.1 and 3.1. 
leverage ratios are permitted (see Weichenrieder and Windischbauer, 2008, for details), or by misdeclaring internal debt as external debt and disguising the ownership in the internal bank. ${ }^{14}$ Such justification and restructuring will, however, cause additional costs for the MNC, which we call 'concealment costs' in the following. Hence, in excess of the safe-harbor share of internal debt $\lambda_{i}$ that is covered by the thin-capitalization rule, affiliates will be able to deduct a further, endogenous share $\beta_{i}^{j}$ of their capital costs in the host country by means of internal debt shifting to a tax haven. The share $\beta_{i}^{j}$ is chosen so as to maximize the difference between the tax gain obtained from these additional transactions and the concealment costs incurred. Concealment costs are assumed to be a linear function of the capital costs and a convex function of the extra leverage share $\beta_{i}^{j}$ and are given by $C_{i}^{j}=(\delta / n)\left(\beta_{i}^{j}\right)^{n} r k_{i}^{j}$, where $n>1$.

The CFC rule allows governments to limit all tax advantages that the domestic MNC obtains from internal leverage. Thus, this instrument applies to both the internal debt within the limit of the legally stipulated thin-capitalization rule $\lambda_{i}$, and to the firm's optimal level of 'excess' leverage $\beta_{i}^{j}$. The tightness of the CFC rule is characterized by the minimum tax rate $\tau^{j}$ that a tax-haven country must levy on the profits of the MNC in order to avoid additional taxation in the MNC's parent country (see Table 1). In the MNC's optimum, the affiliate holding the firm's capital (the 'internal bank' of the MNC) will therefore be located in a tax-haven country $k$ whose statutory tax rate $t_{k}$ is just equal to this lowest possible tax rate that avoids the headquarters country's CFC rules. ${ }^{15}$

\section{$2.2 \quad$ Firms' decision problems}

National firms. Unlike MNCs, the national firms do not have the opportunity to use internal debt as a tax-planning instrument. Costs of capital cannot be deducted from the tax base and hence the corporate tax combines a tax on profits with a 'pure' capital tax. The optimization problem of the national firms reduces to an investment decision. Profits of the national firms are

$$
\pi_{i}^{d}=\left(1-t_{i}\right) g\left(d_{i}\right)-r d_{i}
$$

The optimal investment level is then implicitly defined by the first-order condition

$$
\left(1-t_{i}\right) g^{\prime}\left(d_{i}\right)=r
$$

\footnotetext{
${ }^{14}$ In general, the results of empirical studies indicate that many MNCs are able to deduct interest payments in excess of the limitations imposed by thin-capitalization rules; see, e.g., Blouin et al. (2014).

${ }^{15}$ In general, the MNC will place its internal bank in the affiliate with the lowest effective tax rate; see Mintz and Smart (2004) and Schindler and Schjelderup (2012). In a setting with CFC rules, this affiliate will be the one for which the CFC rule is just not binding.
} 
The effects of an increase in the statutory tax rate $t_{i}$ on the investment levels of national firms are given by

$$
\frac{\partial d_{i}}{\partial t_{i}}=\frac{g^{\prime}\left(d_{i}\right)}{\left(1-t_{h}\right) g^{\prime \prime}\left(d_{i}\right)}<0 \quad \forall i \in\{h, f\} .
$$

Since the costs of financing the investment are not tax-deductible for national firms, but the returns from the investment are taxed, a higher tax rate induces national firms to reduce their investment levels. The governments' remaining tax instruments do not affect national firms.

Multinational firms. Under the ruling international standard of separate accounting, profits are considered separately for each entity of a MNC. For a firm that is headquartered in country $j$ and has an affiliate in country $i$, affiliates' net profits are

$$
\pi_{i}^{j}=\left(1-t_{i}\right) f\left(k_{i}^{j}\right)-\rho_{i}^{j} k_{i}^{j}-\mathbb{1} s k_{i}^{j}
$$

where $\mathbb{1}$ is an indicator which takes the value of unity if $i \neq j$ and zero otherwise. This implies that investment in an affiliate abroad causes additional transaction costs $s$ per unit invested. ${ }^{16}$ The firm-specific capital costs are

$$
\rho_{i}^{j}=\left[1-\left(t_{i}-\tau^{j}\right)\left(\lambda_{i}+\beta_{i}^{j}\right)+\frac{\delta}{n}\left(\beta_{i}^{j}\right)^{n}\right] r .
$$

The capital costs of an affiliate of MNC $j$ in country $i$ are reduced by the tax shield of internal debt, which depends on the host country's tax rate $t_{i}$. However, the tax gain is limited by the fact that the headquarters country's CFC rule leads to the internal bank being located in a tax haven with the tax rate $\tau^{j}$ (where the interest income from the internal loan is taxed). The amount of internal debt that is shifted to the tax haven depends on the share of internal debt $\lambda_{i}$ that is tax-deductible under the thincapitalization rule, and on the excess leverage $\beta_{i}^{j}$. The latter, however, causes concealment costs that reduce the net gain from the extra leverage and increase the capital cost. ${ }^{17}$ The MNC's maximization problem can be seen as a two-stage process in which the affiliate first chooses the profit-maximizing financial structure and then, in a second step, decides on how much to invest and produce in each country. The optimal leverage ratio is

\footnotetext{
${ }^{16}$ These costs incorporate additional information costs, or monitoring costs that are higher when the manager's division is further away from the firm's headquarters (Grossman and Helpman, 2004). Introducing transaction costs for FDI is consistent with the empirical evidence that FDI is falling in the distance between the home and the foreign affiliate of MNCs (Egger and Pfaffermayr, 2004; Kleinert and Toubal, 2010).

${ }^{17}$ From equation (5), we see that the investment costs of an affiliate in country $i$ would be fully taxdeductible, leading to effective capital costs of $\rho_{i}^{j}=\left(1-t_{i}\right) r$, if the headquarters country allowed the internal bank to be placed in a tax haven with a zero tax rate $\left(\tau^{j}=0\right)$ and if there is no binding thin-capitalization rule so that $\lambda_{i}=1$. In this case, the affiliates would not have an incentive to use any extra leverage $\left(\beta_{i}^{j}=0\right)$ and consequently would also not incur any concealment costs.
} 
obtained by minimizing the effective capital cost in (5) with respect to $\beta_{i}^{j}$, giving

$$
\beta_{i}^{j}=\left(\frac{t_{i}-\tau^{j}}{\delta}\right)^{\frac{1}{(n-1)}}
$$

From (6), the effects of the corporate tax rate and the headquarters country's CFC rule on the affiliate's optimal leverage ratio are

$$
\frac{\partial \beta_{i}^{j}}{\partial t_{i}}=\frac{1}{n-1} \frac{\beta_{i}^{j}}{t_{i}-\tau^{j}}>0, \quad \frac{\partial \beta_{i}^{j}}{\partial \tau^{j}}=-\frac{\partial \beta_{i}^{j}}{\partial t_{i}}<0 .
$$

Using (6) in (5) gives the effective capital cost under the optimized financial structure

$$
\left(\rho_{i}^{j}\right)^{*}=\left\{1-\left(t_{i}-\tau^{j}\right) \lambda_{i}-\frac{(n-1)}{n}\left[\frac{\left(t_{i}-\tau^{j}\right)^{n}}{\delta}\right]^{\frac{1}{n-1}}\right\} r .
$$

From equation (8), we can derive the effects of all tax instruments on the effective capital costs of each affiliate. In country $h$, three different entities of MNCs need to be considered: the home affiliate of the domestic MNC, the foreign affiliate of the domestic MNC, and the home affiliate of the foreign MNC. The effect of the home country's tax parameters $t_{h}, \lambda_{h}$ and $\tau^{h}$ on these three firm types are

$$
\begin{gathered}
\frac{\partial \rho_{h}^{h}}{\partial t_{h}}=-\left(\lambda_{h}+\beta_{h}^{h}\right) r, \quad \frac{\partial \rho_{h}^{h}}{\partial \lambda_{h}}=-\left(t_{h}-\tau^{h}\right) r, \quad \frac{\partial \rho_{h}^{h}}{\partial \tau^{h}}=\left(\lambda_{h}+\beta_{h}^{h}\right) r ; \\
\frac{\partial \rho_{h}^{f}}{\partial t_{h}}=-\left(\lambda_{h}+\beta_{h}^{f}\right) r, \quad \frac{\partial \rho_{h}^{f}}{\partial \lambda_{h}}=-\left(t_{h}-\tau^{f}\right) r, \quad \frac{\partial \rho_{h}^{f}}{\partial \tau^{h}}=0 ; \\
\frac{\partial \rho_{f}^{h}}{\partial t_{h}}=0, \quad \frac{\partial \rho_{f}^{h}}{\partial \lambda_{h}}=0, \quad \frac{\partial \rho_{f}^{h}}{\partial \tau^{h}}=\left(\lambda_{f}+\beta_{f}^{h}\right) r .
\end{gathered}
$$

Turning first to the effects on the domestic MNC's home affiliate in (9a), we see that an increase in country $h$ 's statutory tax rate lowers the effective capital costs, because it increases the tax shield of (internal) debt. Similarly, a more lenient thin-capitalization rule reduces the cost of capital by decreasing the corporate tax base. Finally, an increase in $\tau^{h}$, which implies a tightened CFC rule, decreases the gains from debt shifting and therefore results in higher effective capital costs.

Equation (9b) shows the tax effects on the foreign MNC's affiliate in the home country $h$. Changes in $h$ 's statutory tax rate $t_{h}$ and in the thin-capitalization rule $\lambda_{h}$ affect the capital costs of the foreign MNC in a way analogous to the domestic MNC [see eq. (9a)]. However, the foreign MNC is unaffected by a change in the home country's CFC rule $\tau^{h}$. Finally, the tax effects on the home MNC's affiliate in the foreign country $f$ are given in $(9 \mathrm{c})$. This shows that neither the statutory tax rate $t_{h}$ nor the thin-capitalization rule $\lambda_{h}$ affect the effective capital costs of this affiliate. However, country $h$ 's CFC rule applies 
to the domestic firm's affiliate in the foreign country. Thus, an increase in $\tau^{h}$ increases the effective capital costs of this affiliate.

In the first stage all MNCs choose their investment levels, given the optimized financial structure. Maximizing profits in (4) implicitly determines optimal investment by

$$
\left(1-t_{i}\right) f^{\prime}\left(k_{i}^{j}\right)-\rho_{i}^{j}-\mathbb{1} s=0 \quad \forall i, j=h, f .
$$

An increase in the effective capital costs $\rho_{i}^{j}$ decreases investment by

$$
\frac{\partial k_{i}^{j}}{\partial \rho_{i}^{j}}=\frac{1}{\left(1-t_{i}\right) f^{\prime \prime}\left(k_{i}^{j}\right)}<0 \quad \forall i, j=h, f,
$$

which implies that the per-unit transaction cost $s$ does not affect the elasticity with which investment responds to the cost of capital.

Applying the implicit function theorem on (10) and using the effect on the effective capital costs in $(9 a)-(9 c)$, the effects of the home country's statutory tax rate $t_{h}$ on the investment decision of each MNC are

$$
\frac{\partial k_{h}^{j}}{\partial t_{h}}=\frac{f^{\prime}\left(k_{h}^{j}\right)-\left(\lambda_{h}+\beta_{h}^{j}\right)}{\left(1-t_{h}\right) f^{\prime \prime}\left(k_{h}^{j}\right)}<0, j=h, f ; \quad \frac{\partial k_{f}^{h}}{\partial t_{h}}=0 .
$$

Accordingly, the statutory tax rate $t_{h}$ negatively affects investment levels for all affiliates located in country $h$, but not the investment of the foreign affiliate of the domestic MNC. The investment effects of the other tax instruments $\lambda_{h}$ and $\tau^{h}$ then result from the changes in the effective capital costs $(9 a)-(9 c)$, in combination with the negative effect of capital costs on investment levels in (11).

Finally, from (10), a change in the transaction costs of FDI changes the MNC's investment levels by

$$
\frac{\partial k_{i}^{j}}{\partial s}=\frac{1}{\left(1-t_{i}\right) f^{\prime \prime}\left(k_{i}^{j}\right)}<0 \quad i \neq j, \quad \frac{\partial k_{i}^{i}}{\partial s}=0,
$$

and thus affects only the investment level in the foreign affiliate.

\section{Optimal tax policy}

In our general model, we define welfare in country $h$ as a weighted average of domestic tax revenue and the sum of the profits of national firms and the domestic MNC. ${ }^{18}$ Thus

$$
W_{h}=t_{h} \cdot T_{h}+\gamma \cdot \Pi^{h}
$$

\footnotetext{
${ }^{18}$ Note that consumers in the home country are not affected by tax policy in our model, because the price of the single output good is determined in the large world market.
} 
where $T_{h}$ is the total tax base in the home country, $\Pi^{h}=\pi_{d}+\pi_{h}^{h}+\pi_{f}^{h}$ are the total profits of firms headquartered in $h$, and $0 \leq \gamma \leq 1$ is the relative welfare weight placed on domestically-owned firms' profits. The welfare discount on firms' profits either reflects the fact that raising corporate tax revenue is important for society (for redistributive reasons, or to reduce other distortive taxes), or that domestic firms are partly owned by foreign investors that do not enter the domestic welfare function. For $\gamma=0$, we would have a Leviathan government that is solely interested in maximizing its tax revenue.

The domestic tax base $T_{h}$ consists of the sales of all entities producing in country $h$. From this is subtracted the tax cost for the government of permitting the deduction of internal debt for the home affiliates of the domestic and the foreign MNCs:

$$
T_{h}=g\left(d_{h}\right)+f\left(k_{h}^{h}\right)-\left(\lambda_{h}+\beta_{h}^{h}\right) r k_{h}^{h}+f\left(k_{h}^{f}\right)-\left(\lambda_{h}+\beta_{h}^{f}\right) r k_{h}^{f},
$$

The home government (and analogously the foreign government) maximizes national welfare in (14) by choosing the statutory tax rate $t_{h}$, the thin-capitalization rule $\lambda_{h}$ and the CFC rule $\tau^{h}$, subject to the optimal financing and investment decisions of the different firm types discussed in the last section.

Optimal statutory tax rate. The welfare function shows that all types of firms in country $h$ are affected by changes in the statutory tax rate. Differentiating the welfare function with respect to $t_{h}$ implicitly determines the optimal statutory tax rate:

$$
\begin{aligned}
\frac{\partial W_{h}}{\partial t_{h}} & =(1-\gamma)\left[g\left(d_{h}\right)+f\left(k_{h}^{h}\right)-\left(\lambda_{h}+\beta_{h}^{h}\right) r k_{h}^{h}\right]+\left[f\left(k_{h}^{f}\right)-\left(\lambda_{h}+\beta_{h}^{f}\right) r k_{h}^{f}\right] \\
& +t_{h}\left\{g^{\prime}\left(d_{h}\right) \frac{\partial d_{h}}{\partial t_{h}}+\left[f^{\prime}\left(k_{h}^{h}\right)-\left(\lambda_{h}+\beta_{h}^{h}\right) r\right] \frac{\partial k_{h}^{h}}{\partial t_{h}}+\left[f^{\prime}\left(k_{h}^{f}\right)-\left(\lambda_{h}+\beta_{h}^{f}\right) r\right] \frac{\partial k_{h}^{f}}{\partial t_{h}}\right\} \\
& -t_{h} r\left(\frac{\partial \beta_{h}^{h}}{\partial t_{h}} k_{h}^{h}+\frac{\partial \beta_{h}^{f}}{\partial t_{h}} k_{h}^{f}\right)=0 .
\end{aligned}
$$

The first-order condition (16) states that an increase in the statutory tax rate $t_{h}$ increases the welfare in country $h$ due to higher net gains from taxing domestic profits (the first term on the right-hand side) and from the taxation of foreign-owned profits (the second term). However, a higher statutory tax rate also reduces the domestic tax base, and hence tax revenues, as a result of lower investments by all firms that operate in the home market (the third term). Finally, the tax base of the home country is further reduced because all affiliates of MNCs operating in country $h$ have an incentive to increase the variable internal debt level $\beta_{i}^{j}$ (the fourth term).

Evaluating condition (16) at $t_{h}=0$ shows that the negative third and fourth terms vanish at this point, and hence $\partial W_{h} / \partial t_{h}$ is unambiguously positive at $t_{h}=0$. Therefore, the statutory tax rate will always be positive in the government's tax optimum, $t_{h}^{*}>0$. 
Optimal thin-capitalization rule. For any statutory tax rate $t_{h}>0$, granting some tax deductibility of internal debt (i.e., introducing a thin-capitalization rule $\lambda>0$ that is not perfectly strict) reduces the tax base of the MNCs, but it does not affect national firms. Thus, the thin-capitalization rule allows governments to discriminate between national firms and MNCs. Differentiating (14) with respect to $\lambda_{h}$ leads to

$$
\begin{aligned}
\frac{\partial W_{h}}{\partial \lambda_{h}} & =t_{h}\left\{\left[f^{\prime}\left(k_{h}^{h}\right)-\left(\lambda_{h}+\beta_{h}^{h}\right) r\right] \frac{\partial k_{h}^{h}}{\partial \rho_{h}^{h}} \frac{\partial \rho_{h}^{h}}{\partial \lambda_{h}}+\left[f^{\prime}\left(k_{h}^{f}\right)-\left(\lambda_{h}+\beta_{h}^{f}\right) r\right] \frac{\partial k_{h}^{f}}{\partial \rho_{h}^{f}} \frac{\partial \rho_{h}^{f}}{\partial \lambda_{h}}\right\} \\
& -t_{h} r\left(k_{h}^{h}+k_{h}^{f}\right)-\gamma k_{h}^{h} \frac{\partial \rho_{h}^{h}}{\partial \lambda_{h}} \leq 0 .
\end{aligned}
$$

The first term on the right-hand side of (17) is positive, as an increase in $\lambda_{h}$ reduces the effective capital costs and thus induces the home affiliates of the domestic and foreign MNCs to expand their investment in the home country [see (11)]. The second term is negative, however, as a more generous thin-capitalization rule allows MNCs to deduct a higher share of their financing costs from the corporate tax base. Finally, the third term is positive again, as a reduction in its capital costs increases the profits of the domestic MNC's home affiliate.

In sum, the optimal thin-capitalization rule balances the gains from increased investment by MNCs against the net welfare cost of a reduced tax base. To obtain a strictly positive deductibility of internal debt $\lambda_{h}^{*}>0$ in the optimum, the investment by MNCs in country $h$ must be sufficiently elastic, i.e., $\partial k_{h}^{j} / \partial \rho_{h}^{h}, j \in\{h, f\}$ must be sufficiently large. If this is the case, the government will find it optimal to tax-discriminate in favor of MNCs vis-à-vis domestic firms by selectively narrowing the tax base for the former group. ${ }^{19}$ Moreover, the thin-capitalization rule will be more generous ( $\lambda_{h}$ is higher), the higher is the welfare weight of firms' profits $(\gamma)$ in the government's objective function.

We can also infer from (17) under which conditions the governments will set a binding thin-capitalization rule, implying that not all internal debt is tax-deductible and hence $\lambda_{h}^{*}<1$ in the optimum. This requires that the positive investment effect from MNCs (plus the welfare gain from higher firm profits) must not be too large, relative to the negative tax base effect that follows from the deductibility of interest payments. From eq. (11), this will be the case when total capital investment in country $h$ reacts not too strongly to changes in the cost of capital, implying that $f^{\prime \prime}\left(k_{h}^{h}\right)$ and $f^{\prime \prime}\left(k_{h}^{f}\right)$ are relatively large in absolute values. Economically, this means that pure profits are relatively large and the corporation tax thus incorporates a substantial share of pure profit taxation. This condition is likely to be fulfilled for MNCs, which exhibit a high degree of profitability in empirical studies (e.g., Tomiura, 2007; Yeaple, 2009).

\footnotetext{
${ }^{19}$ The result that competing governments will find it in their national interest to grant tax concessions to mobile MNCs by means of a reduced tax base is known from the existing literature on thin-capitalization rules (see Hong and Smart, 2010; Haufler and Runkel, 2012).
} 
Finally, note that we have imposed the restriction on governments that the thin-capitalization rule must be identical for domestic and foreign MNCs (see footnote 6). Conceptually, however, (17) can be separated into two firm-specific thin-capitalization rules that may be different for the home and the foreign MNC. We can define

$$
\begin{aligned}
\Delta^{h} & \equiv\left[f^{\prime}\left(k_{h}^{h}\right)-\left(\lambda_{h}+\beta_{h}^{h}\right) r\right] \frac{\partial k_{h}^{h}}{\partial \rho_{h}^{h}} \frac{\partial \rho_{h}^{h}}{\partial \lambda_{h}}-r k_{h}^{h}-\gamma \frac{k_{h}^{h}}{t_{h}} \frac{\partial \rho_{h}^{h}}{\partial \lambda_{h}}, \\
\Delta^{f} & \equiv\left[f^{\prime}\left(k_{h}^{f}\right)-\left(\lambda_{h}+\beta_{h}^{f}\right) r\right] \frac{\partial k_{h}^{f}}{\partial \rho_{h}^{f}} \frac{\partial \rho_{h}^{f}}{\partial \lambda_{h}}-r k_{h}^{f} .
\end{aligned}
$$

Under symmetry (i.e., $\tau^{h}=\tau^{f}$ ) and the presence of transaction costs $s>0$, the negative second term will be smaller in (18b) as compared to (18a), whereas the positive investment response to a more generous thin-capitalization rule is the same for the two MNCs [see eq. (11)]. Hence, if differentiated thin-capitalization rules were permitted for the home and the foreign MNC, the home country would set a more lenient rule for the foreign MNC, if $s$ is sufficiently high, or if the welfare weight put on firms' profits is sufficiently low. For example, the condition is always fulfilled for a Leviathan government $(\gamma=0)$. Accordingly, given the constraint that thin-capitalization rules have to be equal for both MNCs, the shadow prices in (18a) and (18b) are given by $\Delta^{h}<0$ and $\Delta^{f}>0$. We will use these results in our interpretation of the optimal CFC rule, to which we turn now.

Optimal CFC rule. The CFC rule reduces the tax gain from internal debt by increasing the tax rate in the MNC's internal bank. Consequently, such a rule raises the cost of capital for affiliates of the domestic MNC located in both countries $h$ and $f$. Differentiating the welfare function (14) with respect to $\tau^{h}$ results in

$$
\begin{aligned}
\frac{\partial W_{h}}{\partial \tau^{h}} & =-t_{h} \frac{\partial \beta_{h}^{h}}{\partial \tau^{h}} r k_{h}^{h}+t_{h}\left[f^{\prime}\left(k_{h}^{h}\right)-\left(\lambda_{h}+\beta_{h}^{h}\right) r\right] \frac{\partial k_{h}^{h}}{\partial \rho_{h}^{h}} \frac{\partial \rho_{h}^{h}}{\partial \tau^{h}} \\
& -\gamma\left[k_{h}^{h}\left(\lambda_{h}+\beta_{h}^{h}\right)+k_{f}^{h}\left(\lambda_{f}+\beta_{f}^{h}\right)\right] r \leq 0 .
\end{aligned}
$$

The first term on the right-hand side is positive, showing that a tighter CFC rule increases tax revenues in the home country by reducing the extra leverage $\beta_{h}^{h}$ that the home affiliate of the domestic MNC chooses in its financial optimum. In contrast, the second term is negative, because a tighter $\mathrm{CFC}$ rule increases the effective capital costs of the domestic MNC's home affiliate and this reduces investment and tax revenues. Finally, the third term is also negative as all affiliates of the domestic MNC lose profits due to the higher costs of capital.

The government will only implement a CFC rule if the welfare gains exceed the welfare losses associated with this instrument. Other things equal, this will be the case if internal debt responds elastically to changes in the CFC rule and the positive first term is thus 
large. Moreover, a binding CFC rule (a positive level of $\tau^{h}$ ) is more likely, if the investment response of the domestic MNC's home affiliate is relatively inelastic ( $\partial k_{h}^{h} / \partial \rho_{h}^{h}$ is low in absolute value), and hence if the negative second effect in (19) is rather small. In addition, the CFC rule will also be stricter, other things being equal, the lower is the welfare weight $\gamma$ of the home MNC's profits in the government's objective function.

A last condition emerges when the first-order condition for the optimal CFC rule is rewritten with the help of the optimal thin-capitalization rule in an interior optimum. Using (17) and (18b) gives

$$
\underbrace{-t_{h} \frac{\partial \beta_{h}^{h}}{\partial \tau^{h}} r k_{h}^{h}}_{(+)}+t_{h} \underbrace{\frac{\partial \rho_{h}^{h} / \partial \lambda^{h}}{\partial \rho_{h}^{h} / \partial \tau^{h}}}_{(-)}\left[r k_{h}^{h}-\Delta^{f}\right]-\gamma k_{f}^{h}\left(\lambda_{f}+\beta_{f}^{h}\right) r=0 .
$$

The first term in (20) is positive and unchanged from (19). The intuition for the third term is also the same as in (19). A higher weight on firms' profits abroad reduces the incentive to set a strict CFC rule. The negative second term is now composed of two effects, however, and the negative direct effect $r k_{h}^{h}$ is partly counteracted by a positive shadow price $\Delta^{f}>0$ if transaction costs $s$ are high (or the welfare weight of profits $\gamma$ is low), see (18b). In the interior optimum, the CFC rule $\tau^{h}$ is thus set at a higher level when $\Delta^{f}$ is positive. From our above discussion this implies that the government would want to set a tighter thin-capitalization rule for the domestic as opposed to the foreign MNC. The CFC rule, which increases the capital cost of the domestic, but not of the foreign MNC, thus partly serves to bring about the desired discrimination between the effective taxation of domestic and foreign MNCs.

Summarizing this analysis, we can now answer the question under which conditions a binding CFC rule will be part of an optimal tax policy:

Proposition 1 A binding CFC rule $\left(\tau^{h}>0\right)$ is more likely to be chosen in the government's tax policy optimum, if $(i)$ the financing structure of the domestic $M N C$ responds elastically to this policy change; (ii) the investment of the domestically-owned MNC reacts inelastically to the rise in the capital cost; (iii) the welfare weight of profits in the government objective function is low; (iv) transaction costs s are high and the home government uses the CFC rule to indirectly discriminate between the taxation of domestic and foreign $M N C s$.

Regarding condition $(i)$ in Proposition 1, recent empirical evidence by Egger et al. (2014) indicates that debt shifting in MNCs does indeed respond highly elastically to tax incentives. For a panel of German-owned MNCs, the authors find that a one percentage point increase in the host country's tax rate raises the internal-debt-to-capital ratio of the borrowing affiliate by 0.92 percentage points. ${ }^{20}$ Evidence that simultaneously relates

\footnotetext{
${ }^{20}$ For a meta-study of the earlier empirical evidence on the effects of company taxation on capital
} 
to conditions $(i)$ and $(i i)$ is provided by Mintz and Smart (2004). The authors explicitly compare the responses of Canadian firms that can save provincial taxes via income shifting with those that are able to reduce taxes by the relocation of investment. Mintz and Smart (2004) find that the income shifting response to tax incentives is about twice as large as the investment response. In sum, the existing empirical evidence indicates that the first two conditions in Proposition 1 are indeed likely to be met.

Condition ( iii) indicates that CFC rules are less likely to be part of an optimal tax system when the weight of foreign profits is increased. This could explain why the United States have weakened their pre-existing CFC rules ('subpart F rules') by introducing the socalled 'check-the-box' regime in 1997 (see footnote 8). Grubert (2012) documents, for a sample of more than 750 U.S.-based MNCs, that their average pre-tax share of profits earned abroad has increased from 37 percent in 1996 to 51 percent in 2004. As we have discussed above, a binding CFC rule imposed by the United States will reduce the profits of these foreign affiliates by limiting their incentive to shift internal debt to a tax haven. But this implies that they will pay more tax in the foreign host country, thus reducing U.S. welfare without any offsetting gain to the U.S. treasury. Weakening CFC restrictions by means of check-the-box rules thus allows U.S.-based MNCs to increase their after-tax profits, and partly so at the expense of foreign governments. Finally, the relative importance of the capital stock from inward FDI has significantly increased in the United States during the last three decades, indicating falling transaction costs for FDI. ${ }^{21}$ From condition $(i v)$, this reduces the incentive to use CFC rules as a way to increase the taxation of domestic vis-à-vis foreign MNCs, and hence also works in the direction of laxer CFC rules.

In the following, we assume that the home and the foreign country set interior values of both $\lambda_{i}$ and $\tau^{j}$ in their policy optimum. Table 1 reveals that many countries do indeed simultaneously employ binding CFC rules and binding thin-capitalization rules. Starting from such an interior optimum, we then analyze how economic and financial integration will affect the optimal mix of countries' tax policies vis-à-vis MNCs.

\section{Economic and financial integration}

In this section, we analyze how the government's optimal choice of thin-capitalization and CFC rules is affected by closer international integration. Our model incorporates two exogenous parameters that can be viewed as capturing reduced obstacles for international transactions. The first is the transaction cost parameter for real investment abroad,

structure choice, see Feld et al. (2013).

${ }^{21}$ The FDI inward capital stock, as a percentage of GDP, has roughly tripled in the United States since 1990 (UNCTAD 2015, Annex Table 7). In contrast, the total capital stock, as a share of GDP, has remained roughly constant. 
denoted by $s$. In the following, we label a reduction in this parameter as 'economic integration'. The second relevant parameter is $\delta$, which characterizes the concealment costs for the extra share of debt $(\beta)$ that the MNC shifts to a tax haven. A reduction in $\delta$ will be termed 'financial integration' in what follows.

To determine the comparative-static effects of changes in $s$ and $\delta$ on the simultaneous choices of the thin-capitalization rule $\lambda_{h}$ and the CFC rule $\tau^{h}$, we need to make a number of simplifying assumptions. First, we focus on a Leviathan government that maximizes tax revenues only, and thus set the weight of firms' profits in the government's objective function (14) at $\gamma=0$. Moreover, we assume that the countries $h$ and $f$ are fully symmetric and treat $f^{\prime \prime}(k)$ as constant. Finally, we fix the statutory tax rate $t$ in our analytical derivations, and focus only on the two endogenous 'tax base' parameters $\lambda_{h}$ and $\tau^{h}{ }^{22}$

Totally differentiating the first-order conditions for $\lambda_{h}$ and $\tau^{h}$ in (17) and (19) leads to the following equation set:

$$
\left[\begin{array}{ll}
\alpha_{1} & \alpha_{2} \\
\alpha_{3} & \alpha_{4}
\end{array}\right]\left[\begin{array}{l}
d \lambda_{h} \\
d \tau^{h}
\end{array}\right]=\left[\begin{array}{c}
\alpha_{5} \\
0
\end{array}\right] d s+\left[\begin{array}{l}
\alpha_{6} \\
\alpha_{7}
\end{array}\right] d \delta,
$$

where

$$
\begin{aligned}
\alpha_{1} & =\frac{\partial^{2} W^{h}}{\partial\left(\lambda_{h}\right)^{2}}<0, & \alpha_{2} & =\frac{\partial^{2} W^{h}}{\partial \lambda_{h} \partial \tau^{h}}=\frac{\partial^{2} W^{h}}{\partial \tau^{h} \partial \lambda_{h}}=\alpha_{3}>0, \quad \alpha_{4}=\frac{\partial^{2} W^{h}}{\partial\left(\tau^{h}\right)^{2}}<0, \\
\alpha_{5} & =\frac{\partial^{2} W^{h}}{\partial \lambda_{h} \partial s}<0, & \alpha_{6} & =\frac{\partial^{2} W^{h}}{\partial \lambda_{h} \partial \delta}<0, \quad \alpha_{7}=\frac{\partial^{2} W^{h}}{\partial \tau^{h} \partial \delta}>0 .
\end{aligned}
$$

The terms $\alpha_{1}$ to $\alpha_{7}$ are derived and signed in eqs. (A.1) an (A.4) in Appendix A, under the condition that transaction costs are not too large in the initial equilibrium. ${ }^{23}$

Economic integration. We start by analyzing how a change in the transaction cost parameter $s$ affects the equilibrium policies. Applying Cramer's rule to the equation system (21) and using the signed terms in (22), we immediately arrive at

$$
\frac{d \lambda_{h}}{d s}=\frac{\alpha_{4} \alpha_{5}}{|A|}>0 ; \quad \frac{d \tau^{h}}{d s}=-\frac{\alpha_{3} \alpha_{5}}{|A|}>0,
$$

where $|A|=\alpha_{1} \alpha_{4}-\alpha_{2} \alpha_{3}>0$ to obtain a local maximum (see the appendix).

Hence a reduction in the transaction costs for FDI leads to a tighter thin-capitalization rule (a fall in $\lambda_{h}$ ), but also to a less strict CFC rule (a fall in $\tau^{h}$ ) in the government's policy optimum. The fall in $s$ directly affects the optimal thin-capitalization rule by

\footnotetext{
${ }^{22}$ The statutory tax rate is endogenized in our numerical analysis in Section 5.

${ }^{23}$ The appendix also shows that an interior solution for $\tau^{h}$ in our setting requires that the concealment cost function is not too convex and $1<n<2$.
} 
increasing the capital investment $k_{h}^{f}$ of the foreign MNC's affiliate in the home country; see equation (13). This increases the fiscal cost for the home government of granting a generous deductibility of interest to this foreign-owned affiliate by means of a high level of $\lambda_{h}$. At the same time, the fall in $s$ does not affect the elasticity with which the foreign affiliate reacts to its capital costs $\rho_{h}^{f}$ [see eq. (11)] and therefore does not change the 'benefits' for the home country of granting a higher deductibility of internal debt. In sum, each government has an incentive to tighten its thin-capitalization rule following a reduction in the transaction cost parameter $s$.

The stricter thin-capitalization rule in turn (indirectly) affects the optimal setting of the CFC rule. With a lower level of $\lambda_{h}$, the costs of a stricter CFC rule rise, as domestic investment will fall more strongly in response to a rising minimum tax rate $\tau^{h}$ when the rules for deducting internal debt are tightened. Hence the negative second term in (19) becomes larger. ${ }^{24}$ Since the benefits of a stricter CFC rule in the first term of (19) are unchanged, this implies that it is optimal for the home country to relax the CFC rule by lowering $\tau^{h}$.

We summarize these findings in:

Proposition 2 Increased economic integration (a fall in s) leads to a stricter thincapitalization rule $\left(\lambda_{h}\right.$ falls) and to a laxer CFC rule ( $\tau^{h}$ falls), if the governments maximize tax revenues and transaction costs are sufficiently low initially.

The intuition for Proposition 2 is as follows. The government tightens its thin-capitalization rule in response to increased economic integration, because the higher level of foreign investment in the home country raises the costs of granting tax deductibility of interest for the affiliate of the foreign MNC. In contrast, the investment level of the home MNC remains unchanged. Therefore, the home country would ideally want to tighten the thincapitalization rule for the foreign MNC only. Since the thin-capitalization rule cannot be differentiated for domestic versus foreign MNCs, the second-best policy is to relax the $\mathrm{CFC}$ rule in conjunction with the tighter thin-capitalization rule, so as to reduce the additional tax burden on the domestic MNC.

Financial integration. The effects of a change in the financial integration parameter $\delta$ are more involved because this parameter directly affects the first-order conditions of both optimal policy instruments $\lambda_{h}$ and $\tau^{h}$. In Appendix A [eqs. (A.7) and (A.9)], we show that

$$
\frac{d \lambda_{h}}{d \delta}=\frac{\alpha_{4} \alpha_{6}-\alpha_{2} \alpha_{7}}{|A|}>0, \quad \frac{d \tau^{h}}{d \delta}=\frac{\alpha_{1} \alpha_{7}-\alpha_{3} \alpha_{6}}{|A|}<0
$$

where $|A|>0$ as before.

\footnotetext{
${ }^{24}$ This is true even though the derivative $\partial \rho_{h}^{h} / \partial \tau^{h}$ in (9a) falls when $\lambda_{h}$ is decreased. As is shown in Appendix A, this effect is dominated by the larger value of $\left[f^{\prime}(k)-(\lambda+\beta) r\right]$.
} 
Hence, financial integration (a fall in $\delta$ ) leads to both a tighter thin-capitalization rule $\left(\lambda_{h}\right.$ falls) and a tighter CFC rule ( $\tau^{h}$ rises). The effect on the optimal CFC rule in eq. (19) is straightforward. A lower level of $\delta$ will increase the excess leverage ratio $\beta$ for any given set of optimal policies [see eq. (6)] and this will in turn imply that a tightening of the CFC rule will have a larger beneficial effect on tax revenues [eq. (7)]. Accordingly, the positive first term in (19) increases when $\delta$ is lower. In contrast, the negative effect of the CFC rate on the investment of the home MNC [the second effect in (19)] is not directly affected by a change in $\delta$. In sum, the net benefit from tightening the CFC rule is increased and $\tau^{h}$ rises by the direct effect.

Turning to the optimal thin-capitalization rule, the rise in $\beta$ following a reduction in the financial integration parameter $\delta$ implies that the positive first term in the first-order condition (17) becomes weaker. Intuitively, if $\beta$ is increased, there is less additional revenue to be gained from a given increase in investment that is induced by a more generous thin-capitalization rule. ${ }^{25}$ At the same time, the negative effect on the domestic tax base caused by a more generous thin capitalization rule [the second term in (17)] is unchanged. Therefore, the direct effect of a fall in $\delta$ calls for a tightening of the thin-capitalization rule.

The complication in signing the total effects in (24) arises from the fact that the tightening of each policy instrument $\lambda_{h}$ and $\tau^{h}$ leads to an indirect effect that tends to work in the opposite direction. For example, if a tighter thin-capitalization rule is in place, then a tightening of the CFC rule has a stronger negative effect on the investment of the domestic MNC and this indirect effect tends to work in the direction of reducing $\tau^{h} .{ }^{26}$ As is shown in the appendix, the direct effects dominate the indirect effects for both policy instruments when transaction costs $s$ are sufficiently low, and the exponent $n$ of the concealment cost function is sufficiently bound away from its minimum value of 1 . We can thus summarize:

Proposition 3 Increased financial integration (a fall in $\delta$ ) leads to a stricter thin-capitalization rule $\left(\lambda_{h}\right.$ falls) and to a stricter $C F C$ rule ( $\tau^{h}$ rises), if the government maximizes tax revenues, transaction costs $s$ are small and concealment costs are sufficiently convex ( $n$ is sufficiently larger than 1 ).

The intuition for Proposition 3 is as follows. Financial integration leads to more aggressive tax planning with a larger and more elastic excess leverage $(\beta)$. Therefore, it is beneficial to tighten the thin-capitalization rule (i.e., to reduce the safe-harbor ratio $\lambda$ ) in order to keep total leverage in check. Furthermore, the CFC rule becomes more effective in curbing excessive leveraging and, hence, it should be tightened as well.

\footnotetext{
${ }^{25}$ Once again, this effect dominates the simultaneous change in the derivative $\partial \rho_{h} / \partial \lambda_{h}$. See footnote 24 .

${ }^{26}$ Recall that this indirect effect was responsible for signing the response $d \tau^{h} / d s$ in our analysis of economic integration above. The difference here is that there is a direct effect of $\delta$ on both policy parameters, whereas the direct effect of $s$ on $\tau^{h}$ was zero in the above analysis.
} 
Combining Propositions 2 and 3, we can see that economic and financial integration will both tend to lead to stricter thin-capitalization rules in the government's policy optimum, whereas the effects of economic and financial integration on the optimal CFC rule are mutually offsetting. If we believe that real-world developments in the past decades have included both a fall in the costs of FDI (a fall in $s$ ) and a fall in the cost of moving debt to tax havens (a fall in $\delta$ ), then we should expect to see an unambiguous tightening of thin-capitalization rules, but a less clear picture regarding CFC rules among the countries that do employ such restrictions on debt shifting.

Indeed, the empirical evidence in Table 1 points in this direction. From the 34 OECD countries in our sample, 14 have tightened their thin-capitalization rules during the period 2000-2014 and three more countries switched from a safe-harbor approach to earningsstripping rules in an attempt to tighten their thin-capitalization rules. During the same time period, only one country (the Netherlands) has relaxed its thin-capitalization rule. ${ }^{27}$ In contrast, $\mathrm{CFC}$ rules have been tightened by only eight countries in the sample, and they have been relaxed by three countries (France, Hungary, Japan). Overall, the trend towards a tightening of thin-capitalization rules has therefore been much more pronounced among OECD countries than the trend towards a tightening of CFC rules.

\section{Extensions}

In this section, we analyze three extensions of our basic model. We first endogenize the statutory tax rate and analyze numerically how the tax rate responds to economic and financial integration. We then ask whether the different tax instruments are set too high or too low in the decentralized policy equilibrium, relative to a Pareto efficient benchmark. Finally, we consider an asymmetric policy equilibrium where one country gives a higher weight to domestic corporate profits in its objective function than the other.

Endogenizing the statutory tax rate. A first extension of our analysis is to endogenize the statutory tax rates, which we have held fixed so far. It is not possible to determine analytically the simultaneous changes of variations in the exogenous parameters $s$ and $\delta$ on the three endogenous variables $t, \lambda$, and $\tau$. We can, however, determine these effects by means of numerical calculations. In Table 2, we present the results of some illustrative simulations for the case where both countries $h$ and $f$ simultaneously adjust their optimal tax policies to changes in the exogenous parameters of the model. To interpret the simulation results in Table 2, we first turn to the effects of economic integration in rows (1)-(3). We know from (23) that this change tightens the thin-

\footnotetext{
${ }^{27}$ This trend is even strengthened when the time horizon for the comparison is prolonged. Büttner et al. (2012, p. 930) document that less than one-half of all OECD countries had thin-capitalization rules in the mid-1990s, but two thirds of all OCED countries had enacted thin-capitalization rules by 2005.
} 
Table 2: Simulation results for economic and financial integration

\begin{tabular}{|ccc|cccccccc|}
\hline & $s$ & $\delta$ & $\lambda$ & $\tau$ & $t$ & $\beta$ & $\rho$ & $k_{h}^{h}$ & $k_{f}^{h}$ & $t \times T$ \\
\hline \multicolumn{8}{|c|}{ Economic integration: reduction in $s$} \\
$(1)$ & 0.20 & 0.60 & 0.669 & 0.148 & 0.559 & 0.151 & 0.715 & 9.52 & 5.81 & 36.02 \\
$(2)$ & 0.10 & 0.60 & 0.651 & 0.147 & 0.559 & 0.153 & 0.721 & 9.34 & 7.20 & 36.99 \\
$(3)$ & 0.00 & 0.60 & 0.614 & 0.144 & 0.557 & 0.154 & 0.736 & 9.07 & 9.07 & 38.12 \\
\hline \multicolumn{8}{|c|}{ Financial integration: reduction in $\delta$} \\
$(4)$ & 0.10 & 0.65 & 0.711 & 0.121 & 0.573 & 0.163 & 0.666 & 10.26 & 7.75 & 37.53 \\
$(5)$ & 0.10 & 0.60 & 0.651 & 0.147 & 0.559 & 0.153 & 0.721 & 9.34 & 7.20 & 36.99 \\
$(6)$ & 0.10 & 0.55 & 0.555 & 0.176 & 0.543 & 0.133 & 0.788 & 8.39 & 6.61 & 36.51 \\
\hline
\end{tabular}

Note: Parameters held constant: $r=1, f(k)=10 k^{0.5}, g(d)=10 d^{0.5}, \gamma=0, n=1.2$

capitalization in the government's optimum, but relaxes the CFC rule. These mutually offsetting effects on the corporate tax base imply that the induced changes in the optimal tax rate are small. Similarly, the incentives for firms to use excess leverage $\beta$ and the effects on firms' cost of capital $\rho$ are seen to be moderate. The main change from economic integration is the alignment of domestic and foreign production $\left(k_{h}^{h}\right.$ vs. $\left.k_{f}^{h}\right)$. Since the costs for FDI fall, this is associated with an overall increase in investment that expands the corporate tax base and hence increases tax revenues $(t \times T)$.

The effects of financial integration are shown in rows (4)-(6) of Table 2. From (24), the fall in $\delta$ causes a simultaneous tightening of both the thin-capitalization rule and the CFC rule. With a tax base that is unambiguously broadened, investment of both domestic and foreign firms will respond more elastically to a change in the domestic tax rate, causing the optimal statutory tax rate to fall. ${ }^{28}$ Interestingly, the broadening of the corporate tax base may be so strong that its induced tax rate decrease, in combination with the tax rate increase in the internal bank, causes the excess leverage $\beta$ to fall in equilibrium. In our simulations, the shrinking tax rate differential on internal debt dominates the direct effect of the fall in $\delta$ and causes the costs of capital $\rho$ to rise. This reduces both domestic and foreign investment, as well as overall tax revenues.

The tax competition equilibrium. We consider a decentralized policy equilibrium where each of the two symmetric countries chooses its set of policy measures independently. We assume that an interior equilibrium is reached where the first-order conditions (16), (17), and (19) are all met with equality. It then follows that, starting from a decentralized policy equilibrium, the marginal effect of a change in country $i$ 's policy instrument on the joint welfare of the two regions equals the marginal effect on the welfare of country $j(j \neq i)$. Using the governments' objective (14) and the tax base

\footnotetext{
${ }^{28}$ This corresponds to theoretical results in the literature on optimal thin-capitalization rules; see Hong and Smart (2010), or Haufler and Runkel (2012).
} 
definition (15), it is straightforward to derive

$$
\begin{gathered}
\frac{\partial W_{f}}{\partial t_{h}}=-\gamma\left[f\left(k_{h}^{f}\right)-\left(\lambda_{h}+\beta_{h}^{f}\right) k_{h}^{f} r\right]<0 ; \\
\frac{\partial W_{f}}{\partial \lambda_{h}}=\gamma k_{h}^{f}\left(t_{h}-\tau^{f}\right) r>0 ; \\
\frac{\partial W_{f}}{\partial \tau^{h}}=t_{f}\left\{\left[f^{\prime}\left(k_{f}^{h}\right)-\left(\lambda_{f}+\beta_{f}^{h}\right) r\right] \frac{\partial k_{f}^{h}}{\partial \rho_{f}^{h}} \frac{\partial \rho_{f}^{h}}{\partial \tau^{h}}-\frac{\partial \beta_{f}^{h}}{\partial \tau^{h}} k_{f}^{h} r\right\} .
\end{gathered}
$$

Equation (25) shows that the externalities arising from the statutory tax rate are negative when there is a positive weight of corporate profits in the government objective function $(\gamma>0)$. In other words, the statutory tax rate is too high in the decentralized tax equilibrium, in comparison to the Pareto efficient benchmark. Intuitively, neither $t_{h}$ nor $\lambda_{h}$ affect the cost of capital of country $f$ 's MNC, and hence do not impact tax revenues in country $f$. However, each country taxes the profits of foreign-owned firms that operate within its territory, leading to a transfer of resources from the (foreign) shareholders of the foreign MNC to the domestic treasury. ${ }^{29}$ Similarly, equation (26) shows that the thincapitalization rule is too strict in the decentralized tax equilibrium. Again, this implies a higher effective tax rate on foreign profits, relative to the efficient benchmark, and hence a transfer of resources from foreign shareholders to the domestic government.

Finally, the marginal effect of $\tau^{f}$ in (27) is ambiguous, a priori. We can, however, use the first-order condition for $\tau^{h}$ in (19) to determine the sign of the net effect. If we ignore transaction costs $s$ for simplicity, the two terms in (27) are identical to the first two terms in (19). If we then assume that $\gamma>0$, the sum of the first two terms in (19) must be positive in an interior tax equilibrium. Hence, the sum of the terms in (27) must also be positive, implying that the $\mathrm{CFC}$ rule is set too lax in the decentralized policy equilibrium $\left(\tau^{f}\right.$ is too low). Intuitively, each country allows its domestic MNC to partially escape taxation in the foreign country by shifting profits to the tax haven, thus redistributing income from the foreign treasury to the domestic MNC.

Note that all these externalities disappear when governments maximize tax revenue only and $\gamma=0$ in the government's objective function. In this case, it is immediate from (25) and (26) that the statutory tax rate and the thin-capitalization rule are set at their globally efficient (i.e., tax revenue maximizing) levels. Moreover, the sum of the terms in (27) is then also zero in an interior optimum, if we assume, as before, that $s=0$ and that (19) is met with equality. Intuitively, a tighter CFC rule in country $h$ reduces investment in country $f$, other things being equal, but it also reduces the excess leverage $\beta_{h}^{f}$. These effects will just offset each other when we start from a symmetric tax equilibrium without frictions for FDI.

\footnotetext{
${ }^{29}$ This tax-the-foreigner effect is well-known from the literature; see, e.g., Huizinga and Nielsen (1997).
} 
Table 3: Simulation results for asymmetric countries

\begin{tabular}{|ccc|cccccc|}
\hline & $\gamma_{h}$ & $\gamma_{f}$ & $t_{h}$ & $t_{f}$ & $\lambda_{h}$ & $\lambda_{f}$ & $\tau_{h}$ & $\tau_{f}$ \\
\hline \multicolumn{6}{|c|}{ Differences in the weight of domestic profits } \\
$(1)$ & 0.00 & 0.00 & 0.557 & 0.557 & 0.614 & 0.614 & 0.144 & 0.144 \\
$(2)$ & 0.25 & 0.00 & 0.496 & 0.529 & 0.535 & 0.519 & 0.065 & 0.127 \\
$(3)$ & 0.25 & 0.25 & 0.478 & 0.478 & 0.496 & 0.496 & 0.052 & 0.052 \\
\hline
\end{tabular}

Note: Parameters held constant: $r=1, f(k)=10 k^{0.5}, g(d)=10 d^{0.5}, s=0, \delta=0.6, n=1.2$

Country asymmetries. Finally, we consider the effects of introducing an asymmetry between the two countries. The most straightforward difference between countries is that governments may put different valuations on the profits of domestic firms, relative to the collection of tax revenue. Assume, for example, that the home government has a higher valuation of domestic profits, $\gamma_{h}>\gamma_{f}$. The simulation results in Table 3 show that the home country, i.e., the country with the higher valuation of domestic firms' profits, will have a lower statutory tax rate, a more lenient CFC rule (lower $\tau$ ), but a tighter thin-capitalization rule (a lower level of $\lambda$ ), as compared to the foreign country. It is straightforward to explain the fall in the statutory tax rate from (16), as a higher level of $\gamma$ will reduce the positive first term, and hence the optimal statutory tax rate in this country. Moreover, a more lenient CFC rule can be traced back to (19), where the negative last term is rising in the profit weight parameter $\gamma$, reducing $\tau_{h}$ in the tax optimum.

The effect on the optimal thin-capitalization rule is less clear-cut. The parameter $\gamma$ enters the last term in (17) with a positive weight, implying a higher level of $\lambda_{h}$ in the tax optimum. This positive effect is reinforced by the fall in the statutory tax rate, which enters the first-order condition with a negative sign, on net. At the same time, however, the lower tax rate implies that the investment response to a more generous thin-capitalization rule is now smaller in absolute value, since fewer taxes can be saved [see eq. (11)]. Our simulation results indicate that this last effect will often dominate the other two. Finally, comparing row (3) to row (1) in Table 3 shows that a symmetric equilibrium with still lower tax rates, tighter thin-capitalization rules and more lenient CFC rules emerges when the foreign country also sets a positive weight for the profits of its MNC.

\section{Conclusions}

Many governments have to cope with less tax revenue as multinational companies are exploiting legal arbitrage opportunities in order to shift profits from high-tax to lowtax countries. In response to this development, the OECD calls for introducing and strengthening $\mathrm{CFC}$ rules in its member countries in its 'Action Plan on Base Erosion and 
Profit Shifting'. Many governments have introduced such rules and the recent empirical literature shows that financial and real decisions taken by multinational companies are sensitive to changes in CFC rules. Yet, the theoretical literature has so far neglected the analysis of CFC rules. This paper contributes to filling the gap.

As a first result, we identify the conditions under which binding CFC rules are part of the optimal tax mix chosen by governments. This is the case when the multinationals' internal debt choice responds elastically to the introduction of the CFC rule, and if this outweighs the negative effects on the domestic multinationals' investment decision and on the profits of its foreign affiliates. Secondly, we analyze the effects of economic and financial integration on the optimal level of both thin-capitalization and CFC rules. A fall in the transactions costs of FDI (economic integration) tightens the thin-capitalization rule, but relaxes the CFC rule. In contrast, a fall in the costs of debt shifting to tax havens (financial integration) tightens both the thin-capitalization rule and the CFC rule in the policy optimum. These results are roughly in line with the development of thin-capitalization and CFC rules in the OECD countries over the last two decades.

A more rigorous test of our theoretical predictions for economic integration could be based on UNCTAD's 'Inward FDI Performance Index', which might serve as a proxy for the transaction costs of FDI. Based on our results, a higher score in this index (implying lower transaction costs for FDI) should lead to a tighter thin-capitalization rule, a weaker CFC rule (i.e., a lower minimum tax rate), and a larger share of profits earned abroad. From a theoretical perspective, our analysis of tax competition could be expanded by considering large countries, which are able to affect world interest rates by means of their tax policies. Moreover, we have only briefly touched upon the issue of country asymmetries. An interesting setting would be to consider the tax competition between a large and small country, where the large country is characterized by a relatively larger number of national firms and hence by a lower average elasticity of the corporate tax base. We leave these issues to future research. 


\section{Appendix A: Economic and financial integration}

To determine the signs of the derivatives in (23) and (24), we first derive the $\alpha$-terms given in (22). Using $\beta^{n-1}=(t-\tau) / \delta$ from (6), these are

$$
\begin{aligned}
& \alpha_{1}=\frac{2 t r^{2}}{(1-t) f^{\prime \prime}}(t-\tau)\left[\frac{1-\tau}{1-t}+1\right]<0, \\
& \alpha_{2}=\alpha_{3}=-\frac{t r^{2}}{(1-t) f^{\prime \prime}}\left[\frac{t-\tau}{1-t}(\lambda+\beta)+\frac{\beta}{n-1}-\frac{\left[f^{\prime}(k)-2(\lambda+\beta) r\right]}{r}\right], \\
& \alpha_{4}=-\frac{(2-n) t r k}{(n-1)^{2}} \frac{\beta}{(t-\tau)^{2}}+\frac{t r}{(1-t) f^{\prime \prime}}\left\{\frac{(\lambda+\beta)^{2} r}{1-t}-\frac{\beta\left[f^{\prime}(k)-3(\lambda+\beta) r\right]}{(t-\tau)(n-1)}\right\}<0, \\
& \alpha_{5}=\frac{\left(1-\tau^{h}\right) r}{1-t_{h}} \frac{\partial k}{\partial s}<0, \\
& \alpha_{6}=\frac{2 t r^{2} \beta^{n}}{(1-t) f^{\prime \prime}}\left[\frac{1-\tau}{(1-t)} \frac{1}{n}+\frac{1}{(n-1)}\right]<0, \\
& \alpha_{7}=\frac{t r k}{(n-1)^{2}} \frac{\beta}{\delta(t-\tau)}-\frac{t r}{(1-t) f^{\prime \prime}}\left\{\frac{\beta^{n}(\lambda+\beta) r}{n(1-t)}+\frac{\beta^{2} r}{n(n-1) \delta}-\frac{\beta\left[f^{\prime}(k)-2(\lambda+\beta) r\right]}{(n-1) \delta}\right\} .
\end{aligned}
$$

Among these terms, $\alpha_{4}$ is the second-order condition for the CFC rule $\tau^{h}$; this has to be negative to ensure a maximum. Sufficient conditions for $\alpha_{4}$ to be negative are that $n<2$ in the first term and $\left[f^{\prime}(k)-3(\lambda+\beta) r\right]<0$ in the second term. In what follows, we assume that these conditions are satisfied.

To sign $\alpha_{2}$ and $\alpha_{7}$ we further assume that transaction costs $s$ are small in the initial equilibrium. More precisely, we assume symmetry of countries $h$ and $f$ and $s=0$ in the initial equilibrium, arguing that the resulting conditions will approximately hold also when $s$ is positive, but small. With this assumption and using $\gamma=0$, the first-order condition for the thin-capitalization rule [eq. (17)] simplifies to

$$
\frac{k}{(t-\tau)}=\frac{\left[f^{\prime}(k)-(\lambda+\beta) r\right]}{-(1-t) f^{\prime \prime}}
$$

Using (A.2) in the simplified first-order condition for the CFC rule [eq. (19)] gives

$$
\frac{\beta}{(n-1)}=\lambda+\beta
$$

as a further condition that must hold in an interior, symmetric equilibrium. Using (A.2) and (A.3) in the expressions for $\alpha_{2}$ and $\alpha_{7}$ in (A.1) gives

$$
\alpha_{2}=\alpha_{3}=-\frac{t r^{2}}{(1-t) f^{\prime \prime}}\left[\frac{t-\tau}{(1-t)}(\lambda+\beta)-\frac{\left[f^{\prime}(k)-3(\lambda+\beta) r\right]}{r}\right]>0,
$$




$$
\alpha_{7}=\frac{(2-n) \operatorname{tr} \beta}{(n-1)^{2} \delta} \frac{k}{(t-\tau)}-\frac{t r}{(1-t) f^{\prime \prime}}\left\{\frac{\beta^{n}(\lambda+\beta) r}{n(1-t)}+\frac{\beta^{2} r}{(n-1) \delta}\left[\frac{1}{n}+\frac{1}{(n-1)}\right]\right\}>0
$$

which can now be unambiguously signed from the second-order condition for the optimal CFC rule [the term $\alpha_{4}$ in (A.1)].

We are now able to investigate the sign of the determinant $|A|=\alpha_{1} \alpha_{4}-\alpha_{2} \alpha_{3}$. Using(A.3) and rearranging terms leads to

$$
\begin{aligned}
& \alpha_{1} \alpha_{4}-\alpha_{2} \alpha_{3}= \\
& \frac{2 t^{2} r^{3}}{(1-t)^{2}\left[f^{\prime \prime}\right]^{2}}\left[\frac{1-\tau}{1-t}+1\right] \frac{2-n}{n-1}\left[f^{\prime}(k)-(\lambda+\beta) r\right](\lambda+\beta) \\
& +\frac{t^{2} r^{3}}{(1-t)^{2}\left[f^{\prime \prime}\right]^{2}}\left[\frac{t-\tau}{1-t}+4\right] \frac{t-\tau}{1-t}(\lambda+\beta)^{2} r \\
& -\frac{t^{2} r^{2}}{(1-t)^{2}\left[f^{\prime \prime}\right]^{2}}\left[f^{\prime}(k)-3(\lambda+\beta) r\right]\left[f^{\prime}(k)+(\lambda+\beta) r\right]>0,
\end{aligned}
$$

which is unambiguously positive from the sufficient conditions for the second-order condition $\alpha_{4}$ to be negative.

Economic integration (fall in $s$ ): From the terms in (A.1) and (A.4) we immediately get the effects of changes in the transaction cost parameter $s$ in eq. (23) in the main text.

Financial integration (fall in $\delta$ ): To determine the effects of changes in $\delta$ on the optimal policies $\lambda_{h}$ and $\tau^{h}$ we need to calculate the terms $\alpha_{1} \alpha_{7}-\alpha_{3} \alpha_{6}$ and $\alpha_{4} \alpha_{6}-\alpha_{2} \alpha_{7}$ [cf. eq. (24)]. For the effect on the CFC rule $\tau^{h}$, we get, after rearranging terms

$$
\begin{aligned}
& \alpha_{1} \alpha_{7}-\alpha_{3} \alpha_{6}= \\
& \frac{2 t^{2} r^{3}}{(1-t)^{2}\left(f^{\prime \prime}\right)^{2}} \frac{\beta}{n-1} \frac{1-\tau}{1-t} \frac{(1-t) k f^{\prime \prime}}{\delta(n-1)} \\
& +\frac{2 t^{2} r^{3}}{(1-t)^{2}\left(f^{\prime \prime}\right)^{2}} \frac{\beta}{n-1} \frac{1-\tau}{1-t} \frac{\beta^{n-1}}{n}\left[f^{\prime}-(\lambda+\beta) r\right] \\
& +\frac{2 t^{2} r^{3}}{(1-t) f^{\prime \prime}} \frac{\beta}{n-1} \frac{k}{\delta(n-1)} .
\end{aligned}
$$

Using (A.2) and simplifying results in

$$
\alpha_{1} \alpha_{7}-\alpha_{3} \alpha_{6}=-\frac{2 t^{2}(1-\tau)(t-\tau) r^{3}}{\delta(1-t)^{3}\left(f^{\prime \prime}\right)^{2}} \frac{\beta\left[f^{\prime}-(\lambda+\beta) r\right]}{n(n-1)^{2}}+\frac{2 t^{2} r^{3} \beta k}{(1-t) f^{\prime \prime}(n-1)^{2} \delta}<0
$$


For the effect on the thin-capitalization rule $\lambda_{h}$, we get

$$
\begin{aligned}
& \alpha_{4} \alpha_{6}-\alpha_{2} \alpha_{7}= \\
& +\frac{2 t^{2} r^{2}}{\delta(1-t)^{2}\left(f^{\prime \prime}\right)^{2}} \frac{\beta}{(n-1)^{2}}\left[\frac{1-\tau}{1-t} \frac{\beta r}{n}+\frac{\beta r}{n-1}\right](2-n)\left[f^{\prime}-(\lambda+\beta) r\right] \\
& -\frac{2 t^{2} r^{2}}{\delta(1-t)^{2}\left(f^{\prime \prime}\right)^{2}} \frac{\beta}{n-1}\left[\frac{1-\tau}{1-t} \frac{\beta r}{n}+\frac{\beta r}{n-1}\right]\left[\phi-\frac{1-\tau}{1-t}(\lambda+\beta) r\right] \\
& +\frac{t^{2} r^{2}}{\delta(1-t)^{2}\left(f^{\prime \prime}\right)^{2}} \frac{\beta}{(n-1)^{2}}\left[\phi-\frac{1-\tau}{1-t}(\lambda+\beta) r\right]\left[f^{\prime}-(\lambda+\beta) r\right] \\
& -\frac{t^{2} r^{2}}{\delta(1-t)^{2}\left(f^{\prime \prime}\right)^{2}} \frac{\beta}{n-1}\left[\phi-\frac{1-\tau}{1-t}(\lambda+\beta) r\right]\left[\phi-\frac{\beta r}{n} \frac{1-\tau}{1-t}\right],
\end{aligned}
$$

where $\phi=f^{\prime}-2(\lambda+\beta)$. After some simplifications, we arrive at

$$
\begin{aligned}
& \alpha_{4} \alpha_{6}-\alpha_{2} \alpha_{7}=\frac{(2-n) t^{2} r^{2} \beta\left[f^{\prime}-(\lambda+\beta) r\right]}{(1-t)^{2}\left(f^{\prime \prime}\right)^{2}(n-1)^{2} \delta}\left[f^{\prime}-\frac{(2-n)}{n} \frac{(1-\tau)}{(1-t)}(\lambda+\beta) r\right] \\
& -\frac{t^{2} r^{3} \beta^{2}}{\delta(1-t)^{2}\left(f^{\prime \prime}\right)^{2}(n-1)}\left\{f^{\prime}-(\lambda+\beta) r\left[3+\frac{(t-\tau)}{(1-t)}\right]\right\}\left[\frac{(1-\tau)}{(1-t)} \frac{1}{n}+\frac{1}{(n-1)}\right] .
\end{aligned}
$$

In (A.9), the second term is positive since $\left[f^{\prime}-3(\lambda+\beta) r\right]<0$ from the second-order condition $\alpha_{4}$ in (A.1). Since $(2-n)>0$ the first term is also positive provided that $n>1$ is sufficiently above unity. Equations (A.7) and (A.9) then sign (24) in the main text. 


\section{References}

Altshuler, R., and G. Hubbard (2003). The effect of the Tax Reform Act of 1986 on the location of assets in financial services firms. Journal of Public Economics 87, 109-127.

Becker, J., and C. Fuest (2010). Taxing foreign profits with international mergers and qcquisitions. International Economic Review 51, 171-186.

Bergin, T., 2012. Tax-free Latte. Starbucks Slips the UK Tax Hook. Reuters Special Report, Thomson Reuters. http://graphics.thomsonreuters.com/12/10/Starbucks.pdf.

Blouin, J.L., and L.K. Krull, 2015. Does organizational form affect firm's foreign operations? The role of 'check-the-box' on multinational tax planning. Mimeo, Wharton School and University of Oregon.

Blouin, J.L., H. Huizinga, L. Laeven, and G. Nicodème (2014). Thin-capitalization rules and multinational firm capital structure. CentER Working Paper No. 2014-007, Tilburg University.

Bucovetsky, S., and A. Haufler (2008). Tax competition when firms choose their organizational form: Should tax loopholes for multinationals be closed? Journal of International Economics 74, 188-201.

Büttner, T., M. Overesch, U. Schreiber, and G. Wamser (2012). The impact of thincapitalization rules on the capital structure of multinational firms. Journal of Public Economics 96, 930-938.

Büttner, T., M. Overesch, and G. Wamser (2014). Anti-profit shifting rules and foreign direct investment. CESifo Working Paper No. 4710, Munich.

Deloitte (2014). Guide to controlled foreign company regimes. http://www2.deloitte.com/ global/en/pages/tax/articles/guide-to-controlled-foreign-company-regimes.html

Dharmapala, D., Hines, J.R. (2009). Which countries become tax havens? Journal of Public Economics 93, 1058-1068.

Dischinger, M., and N. Riedel (2011). Corporate taxes and the location of intangible assets within multinational firms. Journal of Public Economics 95, 691-707.

Egger, P., Ch. Keuschnigg, V. Merlo, and G. Wamser (2014). Corporate taxes and internal borrowing within multinational firms. American Economic Journal: Economic Policy 6, 54-93. 
Egger, P., and G. Wamser (2015). The impact of controlled foreign company legislation on real investments abroad: A multi-dimensional regression discontinuity design. Journal of Public Economics 129, 77-91.

Egger, P., and M. Pfaffermayr (2004). Distance, trade and FDI: A SUR Hausman-Taylor approach. Journal of Applied Econometrics 19, 227-246.

Ernst \& Young (2014). Worldwide corporate tax guide. www.ey.com/GL/en/Services/ Tax/Global-tax-guide-archive

Feld, L., J. Heckemeyer, and M. Overesch (2013). Capital structure choice and company taxation: A meta-study. Journal of Banking and Finance 37, 2850-2866.

Grossman, G.M., Helpman, E. (2004). Managerial incentives and the international organization of production. Journal of International Economics 63, 237-262.

Grubert, H. (2012). Foreign taxes and the growing share of U.S. multinational company income abroad: Profits, not sales, are being globalized. National Tax Journal 65, $247-282$.

Haufler, A., and M. Runkel (2012). Firms' financial choices and thin-capitalization rules under corporate tax competition. European Economic Review 56, 1087-1103.

Hong, Q., and M. Smart, (2010). In praise of tax havens: International tax planning and foreign direct investment. European Economic Review 54, 82-95.

Huizinga, H., and S.B. Nielsen (1997). Capital income and profit taxation with foreign ownership of firms. Journal of International Economics 42, 149-165.

Keuschnigg, Ch., and M. Devereux (2013). The arm's length principle and distortions to multinational firm organization. Journal of International Economics 89, 432-440.

Kleinert, J., and F. Toubal (2010). Gravity for FDI. Review of International Economics 18, 1-13.

Lang, M., H.-J. Aigner, U. Scheuerle, and M. Stefaner (2004). CFC legislation, tax treaties and EC law. Linde, Wien.

Mardan, M. (2015). Why countries differ in thin capitalization rules: the role of financial development. CESifo Working Paper No. 5295, Munich.

Mintz, J., and M. Smart (2004). Income shifting, investment, and tax competition: theory and evidence from provincial taxation in Canada. Journal of Public Economics 88, 1149-1168. 
Mutti, J., and H. Grubert (2006). New developments in the effect of taxes on royalties and the migration of intangible assets abroad. Paper prepared for the NBER/CRIW Conference on International Service Flows, Washington.

OECD (2013). Action plan on base erosion and profit shifting. OECD Publishing, Paris. http://dx.doi.org/10.1787/9789264202719-en

OECD (2015). Designing effective controlled foreign company rules. BEPS ACTION 3: 2015 Final Report. Paris. http://dx.doi.org/10.1787/9789264241152-en.

Overesch, M., and G. Wamser (2010). Corporate tax planning and thin-capitalization rules: Evidence from a quasi-experiment. Applied Economics 42, 563-573.

Peralta, S., X. Wauthy, and T. van Ypersele (2006). Should countries control international profit shifting? Journal of International Economics 68, 24-37.

Ruf, M., and D. Schindler (2015). Debt shifting and thin-capitalization rules - German experience and alternative approaches. Nordic Tax Journal 2015:1, 17-33.

Ruf, M., and A.J. Weichenrieder (2012). The taxation of passive foreign investments: Lessons from German experience. Canadian Journal of Economics 45, 1504-1528.

Ruf, M., and A.J. Weichenrieder (2013). CFC rules after Cadbury-Schweppes. CESifo Working Paper No. 4461, Munich.

Schindler, D., and G. Schjelderup (2012). Debt shifting and ownership structure. European Economic Review 56, 635-647.

Tomiura, E. (2007). Foreign outsourcing, exporting and FDI: A productivity comparison at the firm level. Journal of International Economics 72, 113-127.

UNCTAD (2015). World investment report 2015. Geneva. http://unctad.org/en/Pages/ DIAE/World\%20Investment\%20Report/Annex-Tables.aspx

Weichenrieder, A.J. (1996). Anti-tax-avoidance provisions and the size of foreign direct investment. International Tax and Public Finance 3, 67-81.

Weichenrieder, A.J., and H. Windischbauer (2008). Thin-capitalization rules and company responses: Experience from German legislation. CESifo Working Paper No. 2456, Munich.

Yeaple, S.R. (2009). Firm heterogeneity and the structure of U.S. multinational activity. Journal of International Economics 78, 206-215. 
Table 1: CFC Rules and Thin-Capitalization Rules in OECD Countries: 2000 (2004) and 2014

\begin{tabular}{|c|c|c|c|c|c|c|c|c|c|c|}
\hline \multirow[t]{2}{*}{ country } & \multicolumn{4}{|c|}{$2000(2004)$} & \multicolumn{4}{|c|}{2014} & \multicolumn{2}{|c|}{ change } \\
\hline & CIT & CFC rule ${ }^{a}$ & TCR type & ratio & CIT & $\mathrm{CFC}$ rule ${ }^{a}$ & TCR type & ratio & $\mathrm{CFC}^{c, d}$ & $\mathrm{TCR}^{c}$ \\
\hline Australia ${ }^{e}$ & 30 & $\mathrm{BL}^{f}$ & SHR & $3: 1$ & 30 & $\mathrm{BL}$ & SHR & $1.5: 1$ & 0 & + \\
\hline Austria ${ }^{e}$ & 34 & - & - & - & 25 & - & - & - & 0 & 0 \\
\hline Belgium $^{e}$ & 33.99 & - & - & - & 33.99 & & SHR & $5: 1$ & 0 & + \\
\hline Canada & 28 & 28 & SHR & $2: 1$ & 26.5 & 26.5 & SHR & $1.5: 1$ & 0 & + \\
\hline Chile & 17 & - & SHR & $3: 1$ & 20 & - & SHR & $3: 1$ & 0 & 0 \\
\hline Czech Republic $^{e}$ & 28 & - & SHR & $4: 1$ & 19 & - & SHR & $4: 1$ & 0 & 0 \\
\hline Denmark $^{e}$ & 30 & 30 & SHR & $4: 1$ & 24.5 & 24.5 & SHR/ESR & 4:1/80\% EBIT & 0 & + \\
\hline Estonia $^{e}$ & 35 & - & - & - & 21 & 7 & - & - & + & 0 \\
\hline Finland & 29 & 17.4 & - & - & 20 & 12 & ESR & $25 \%$ EBITDA & 0 & + \\
\hline France $^{e}$ & 33.33 & 22.22 & SHR/ESR & $1.5: 1$ & 33.33 & 16.67 & SHR & 1.5:1/25\% EBITDA & - & + \\
\hline Germany & 40 & 30 & SHR & $3: 1$ & 30 & 25 & ESR & $30 \%$ EBITDA & + & $\mathrm{SC}^{g}$ \\
\hline Greece $^{e}$ & 35 & - & - & - & 26 & $13+\mathrm{BL}$ & ESR & $60 \%$ EBITDA & + & + \\
\hline Hungary & 18 & 10 & SHR & $3: 1$ & $19^{h}$ & 10 & SHR & $3: 1$ & - & 0 \\
\hline Iceland $^{e}$ & 18 & - & - & - & 20 & 13.33 & - & - & + & 0 \\
\hline Ireland $^{e}$ & 12.5 & - & - & - & 12.5 & - & - & - & 0 & 0 \\
\hline Israel $^{e}$ & 36 & 20 & - & - & 26.5 & 15 & - & - & + & 0 \\
\hline Italy & 37 & $\mathrm{BL}$ & - & - & 27.5 & $13.75+\mathrm{BL}$ & ESR & $30 \%$ EBITDA & + & + \\
\hline $\operatorname{Japan}^{e}$ & 30 & 25 & SHR & $3: 1$ & 25.5 & 20 & SHR/ESR & 3:1/50\% EBITDA & - & + \\
\hline Korea (Rep.) $)^{e}$ & 37 & 15 & SHR & $3: 1$ & 22 & 15 & SHR & $3: 1$ & + & 0 \\
\hline Luxembourg $^{e}$ & 30.38 & - & SHR & $85: 15$ & 21 & - & SHR & $85: 15$ & 0 & 0 \\
\hline Mexico $^{e}$ & 33 & $\mathrm{BL}$ & - & - & 30 & BL & SHR & $3: 1$ & 0 & + \\
\hline Netherlands ${ }^{e}$ & 34.5 & - & SHR & $3: 1$ & 25 & - & - & - & 0 & - \\
\hline New Zealand ${ }^{e}$ & 33 & 33 & SHR & $3: 1$ & 28 & 28 & SHR & $1.5: 1$ & 0 & + \\
\hline Norway & 28 & 18.67 & - & - & 27 & 18 & ESR & $30 \%$ EBITDA & 0 & + \\
\hline Poland & 19 & - & SHR & $3: 1$ & 19 & - & SHR & $3: 1$ & 0 & 0 \\
\hline Portugal & 25 & $15+\mathrm{BL}$ & SHR & $2: 1$ & 23 & $13.8+\mathrm{BL}$ & ESR & $50 \%$ EBITDA & 0 & $\mathrm{SC}$ \\
\hline
\end{tabular}


Table 1: CFC Rules and Thin-Capitalization Rules in OECD Countries: 2000 (2004) and 2014 continued

\begin{tabular}{|c|c|c|c|c|c|c|c|c|c|c|}
\hline \multirow[t]{2}{*}{ country } & \multicolumn{4}{|c|}{$2000(2004)$} & \multicolumn{4}{|c|}{2014} & \multicolumn{2}{|c|}{ change } \\
\hline & CIT & $\mathrm{CFC}_{\text {rule }}{ }^{a}$ & TCR type & ratio & CIT & CFC rule ${ }^{a}$ & TCR type & ratio & $\mathrm{CFC}^{c, d}$ & $\mathrm{TCR}^{c}$ \\
\hline Slovak Republic & 19 & - & - & - & 22 & - & - & - & 0 & 0 \\
\hline Slovenia & 25 & - & - & - & 17 & - & SHR & $4: 1$ & 0 & + \\
\hline Spain & 35 & $26.25+\mathrm{BL}$ & SHR & $3: 1$ & 30 & $22.5+\mathrm{BL}$ & ESR & $30 \%$ EBITDA & 0 & $\mathrm{SC}$ \\
\hline Sweden & 28 & 15.4 & - & - & 22 & 12.1 & - & - & 0 & 0 \\
\hline Switzerland & 24.1 & - & $\mathrm{ACS}^{h}$ & - & 17.9 & - & $\mathrm{ACS}$ & - & 0 & 0 \\
\hline Turkey $^{e}$ & 30 & - & - & - & 20 & 10 & SHR & $3: 1$ & + & + \\
\hline UK & 30 & 22.5 & - & - & 21 & 15.75 & - & - & 0 & 0 \\
\hline US & 39 & 39 & SHR & $1.5: 1$ & 39 & 39 & SHR & $1.5: 1$ & 0 & 0 \\
\hline
\end{tabular}

a Minimum statutory tax rate in host country.

$b$ Safe haven rule (SHR) or earnings stripping rule (ESR) with amount of interest income up to which interest payments are deductible.

$c$ Tightened rule indicated by + , relaxed rule by - , unchanged rule by 0 .

$d$ Comparison refers to the CFC rule as a percentage share of the residence country's CIT rate.

e First set of entries refers to year 2004 .

$f$ Income arising in black-listed jurisdictions is taxed in the residence country.

$g$ System change towards earnings-stripping rules intended to tighten possibilities for thin-capitalization.

$h$ The first 500m HUF (approx. 1.6m Euro) of income are taxed at a rate of $10 \%$.

$i$ Asset-class specific.

Sources: International Bureau of Fiscal Documentation: European Tax Handbook (2000, 2014); Ernst \& Young Global Tax Guide 2004 and 2014 (http://www.ey.com/GL/en/Services/Tax/Global-tax-guide-archive); OECD Tax Database

(http://www.oecd.org/tax/tax-policy/tax-database.htm) 